\title{
A reading of the leper's healing in Matthew 8:1-4 through ethnomedical anthropology
}

\begin{tabular}{|c|c|}
\hline $\begin{array}{l}\text { Author: } \\
\text { Fednand M. }\end{array}$ & I'bwangi ${ }^{1,2}$ \\
\hline $\begin{array}{l}\text { Affiliations: } \\
{ }^{1} \text { Department } \\
\text { and Religious } \\
\text { of Humanities } \\
\text { Sciences, Pwa } \\
\text { Kilifi, Kenya }\end{array}$ & $\begin{array}{l}\text { Studies, Faculty } \\
\text { Philosophy } \\
\text { and Social } \\
\text { ni University, }\end{array}$ \\
\hline $\begin{array}{l}{ }^{2} \text { Department } \\
\text { Testament an } \\
\text { Literature, Fac } \\
\text { and Religion, } \\
\text { Pretoria, Pret }\end{array}$ & $\begin{array}{l}\text { f New } \\
\text { Related } \\
\text { ulty of Theology } \\
\text { Iniversity of } \\
\text { ria, South Africa }\end{array}$ \\
\hline $\begin{array}{l}\text { Research Proj } \\
\text { Project Leade } \\
\text { Project Numb }\end{array}$ & $\begin{array}{l}\text { ect Registration: } \\
\text { : E. van Eck (D) } \\
\text { er: } 2400030\end{array}$ \\
\hline $\begin{array}{l}\text { Description: } \\
\text { The author is } \\
\text { the research } \\
\text { Platform for } \\
\text { directed by Pr } \\
\text { Eck, Departm } \\
\text { Testament an } \\
\text { Literature, Fac } \\
\text { and Religion, } \\
\text { Pretoria. }\end{array}$ & $\begin{array}{l}\text { oarticipating in } \\
\text { roject 'Africa } \\
\text { T Scholars' } \\
\text { of. Dr Ernest van } \\
\text { nt of New } \\
\text { Related } \\
\text { ulty of Theology } \\
\text { Jniversity of }\end{array}$ \\
\hline $\begin{array}{l}\text { Correspondin } \\
\text { Fednand M'b } \\
\text { manjewarev@ }\end{array}$ & $\begin{array}{l}\text { g author: } \\
\text { vangi, } \\
\text { gmail.com }\end{array}$ \\
\hline $\begin{array}{l}\text { Dates: } \\
\text { Received: } 03 \\
\text { Accepted: } 02 \\
\text { Published: } 26\end{array}$ & $\begin{array}{l}\text { May } 2021 \\
\text { lune } 2021 \\
\text { Aug. } 2021\end{array}$ \\
\hline $\begin{array}{l}\text { How to cite th } \\
\text { M'bwangi, F.N } \\
\text { reading of the } \\
\text { in Matthew 8: } \\
\text { ethnomedical } \\
\text { HTS Teologies } \\
\text { Theological St } \\
\text { a6803. https:/ } \\
\text { org/10.4102/ }\end{array}$ & $\begin{array}{l}\text { is article: } \\
\text {., 2021, 'A } \\
\text { leper's healing } \\
\text { 1-4 through } \\
\text { anthropology', } \\
\text { Studies/ } \\
\text { udies 77(1), } \\
\text { /doi. } \\
\text { its.v77i1.6803 }\end{array}$ \\
\hline $\begin{array}{l}\text { Copyright: } \\
\text { (C) 2021. The } \\
\text { Licensee: AOS } \\
\text { is licensed un } \\
\text { Creative Com } \\
\text { Attribution Lic }\end{array}$ & $\begin{array}{l}\text { uthors. } \\
\text { IS. This work } \\
\text { ler the } \\
\text { nons } \\
\text { ense. }\end{array}$ \\
\hline Read online: & \\
\hline 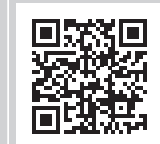 & $\begin{array}{l}\text { Scan this QR } \\
\text { code with your } \\
\text { smart phone or } \\
\text { mobile device } \\
\text { to read online. }\end{array}$ \\
\hline
\end{tabular}

Scholars offer several options for Matthew's value of the leper's story in his narrative that range from revealing Jesus' attributes of compassion and sympathy, manifesting God's empire, to portraying Jesus' function as a temple. Although these suggestions aptly portray Matthew's rhetorical use of the leper's healing in his narrative to address societal concerns of his time, for lack of referring to the social setting of the narrative, they do not capture the holistic healthcare system embodied by Jesus in Matthew's narrative that portrays Jesus as a superior healer to the rest of the other healers in the Roman Empire. The findings of the research for this article establish the argument that employing ethnomedical anthropology as a lens to read the leper's healing narrative in Matthew 8:1-4 in the context of Matthew's social setting reveals Matthew's ideology for a transcendent and immanent Christology. The aim of the article is to demonstrate the effectiveness of medical anthropological theory in explaining the dynamics of health and healing reflected in biblical texts.

Contributions: This article contributes to the interdisciplinary approach to the study of religion by employing a ethnomedical anthropological perspective to read the leper's healing in Matthew 8.1-4 in reference to the first century CE health systems in the Roman Empire. This approach procured that Matthew's immanent and transcendent perspectives of Christology is crucial in demonstrating the text's function in constructing and sustaining the identity of Matthew's community in antiquity.

Keywords: ethnomedical anthropology; Christology; healing; ideology; Matthew 8:1-4; Roman Empire; leper.

\section{Introduction}

The criticism of the South African National Coronavirus Command Council by members of the South Africa Academy of Sciences for excluding social sciences scientist and humanity scholars among medical experts such as epidemiologists, vaccinologists and infectious disease experts to address the advent of the coronavirus in South Africa, ${ }^{1}$ reveals the importance of an interdisciplinary approach to pandemic matters. An interdisciplinary approach to health issues has the capacity to reveal the significance of social and cultural beliefs, norms and traditions associated with illness that are often overlooked by a western evidence-based biomedical profession. An interdisciplinary approach to health matters in the society facilitated the unravelling of the complexity of healing and health issues in the society as early as the first century CE. Recently New Testament scholars have increasingly developed and embraced interdisciplinary approaches to study complex issues of health and healing in the discourse of the early Christian communities. For instance, in his article, 'Aretology of the Best Healer: Performance and Praise of Mark's Healing Jesus', Dube (2018) applies Greek aretological rhetoric and Zulu Praise Izibongo, to defend his hypothesis that Mark's rhetoric of healing the leper in 1:40-45, praises the benefactor (Jesus) vis-à-vis healers who were popular in the first century CE such as Apollonius and Asclepius. Similarly, ethnomedical anthropology has been used by New Testament scholars to explore healing in the discourses of early Christian communities. For instance, Glessner (2017) has applied it to explore the significance of the 'thorn in the flesh' in 2 Corinthians 12:7. Wilson (2014), whose monograph provides the departure for this study, has applied medical anthropology to explore healing narratives in the Gospel of Matthew. To this end, a brief review of research on the significance of the narrative of leper's healing (Mt 8:1-4) is crucial to determine the question and argument to be addressed in this article.

1.See Carruthers, J., (ed.), 'Public statement on Covid-19', South Africa Journal of Science 116(7/8), 32. Also see https://bloomgist. wordpress.com /tag/south-africa/ (Naicker 2020). 


\section{Research sample on Matthew's healing narratives}

A research sample concerning the Gospel of Matthew shows that the significance of the healing of a leper in Matthew 8.1-4 has been a matter of debate among New Testament scholars. Although a comparison between Morris, who regards the narrative as a pointer to the significance of Jesus' attributes, namely, Jesus' compassion and sympathy, and Carter, who claims it manifests God's empire, ${ }^{2}$ does not emphasise the importance of the first century CE social setting in shaping the healing of the leper's narrative in Matthew 8:1-4, nonetheless, their research collectively gives a glimpse of the advancement in the trend of research concerning Matthew's healing narratives: from using biblical criticism only to an interdisciplinary approach that blends literary analysis with social sciences to expose the social and cultural complexities embedded in the biblical texts that often evade biblical criticism approach. Although ethnomedical anthropological reading of the Leper's narrative enables Wilson to see a Christological perspective derived from the significance of Jesus as the temple, ${ }^{3}$ he does this by passing, that is, without espousing Matthew's ideology embedded in this narrative. In view of this brief sample of research, this article strives to answer this question: how does the narrative of the leper's healing in Matthew 8:1-4 reflect Matthew's ideology (mindset) that informs his perspective of Christology? Wilson's observations provide the point of departure for this article, whereby the efficacy of ethnomedical anthropology is stretched further to reveal Matthew's ideology. This article takes a departure from Wilson's research findings.

For the purpose of this study, the author has used qualitative research methodology that derives from a combination of literary analysis with ethnomedical anthropology to uncover Matthew's ideology which is embedded in his narrative of the leper's healing (Mt 8:1-4). To this end, the study takes cognizance of the healing narratives in the Hippocratic discourses on The Sacred Diseases, Myths' on Asclepius' healing power, Pliny's Natural History, Philastratus' Life of Apollonius, and Josephus's Antiquities of the Jews (8:45-49) as primary sources that inform the conception and practice of healing in the first century CE. Consequently, these healing narratives are important to this study not only because they

\footnotetext{
2.For instance, in his monograph, "The Gospel According to Matthew", Morris, using source criticism, suggests that this healing of a leper when viewed in the context of the healing of the Gentile $(8: 5-13)$ and that of Peter's mother $(8: 14-17)$ reveals the significance of Jesus' attributes, namely, Jesus' compassion and sympathy (Morris 1992:187). In his monograph, "Matthew and the Margins: A Sociopolitical and Religious Reading", Carter, employing a socio-political perspective, regards the words and actions of Jesus in this healing manifesting God's empire that 'established Jesus as the revealer and liberator' (Carter 2000:198).

3.In his work, "Healing in the Gospel of Matthew", employing literary analysis and ethnomedical anthropology, Wilson (2014) suggests that the combination of works and words in Matthew's healing narrative of the leper indicates the function of Jesus as the Temple. Underscoring his conception of the Temple function of Jesus, Wilson (2014:16, 43-47) regards Jesus as 'the living embodiment of a cultic center of healing' and in effect contributes to Matthew's perspective of Christology a of healing and in effect contributes to Matthew's perspective of Christology position which of course emphasises the social-cultural function of the Jerusalem Temple in espousing the meaning of Matthew's Gospel narratives. However, Wilson only briefly mentions the connection of the leper's healing with Matthew's Christology without explaining how the leper's narrative reflects the dynamics of Matthew's mindset that informs his perspective of Christology.
}

provide the backdrop to the significance of the healing of the leper in Matthew 8:1-4, but they also outline the first century social setting from which the community of Matthew emerged in the late first century CE. By pursuing a pathway that takes cognizance of the first century social setting of the community of Matthew, this article strives to defend the argument that applying ethnomedical anthropology to critically read the leper's healing in Matthew 8:1-4 reveals Matthew's ideology for his Christology embedded in his healing narratives. The main ideological function of this Christology is to reconstruct and sustain the identity of Matthew's community. To this end, a semantic analysis of Matthew 8:1-4 is crucial before outlining the tenets of the perspectives of ethnomedical anthropological appropriate for this study.

\section{Semantic analysis of Matthew 8:1-4 \\ Matthew 8:1-2: A crowd witnessed the healing}

In this analysis the author has used Greek Text, which is translated into English along the way, to refer to a text in the Gospel of Matthew. The sentence flow of verse 1 presents a close connection between Jesus descent from the mount and the emergence of the crowd.

$\delta \grave{\varepsilon}$

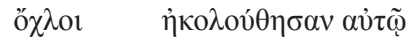

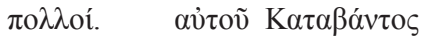

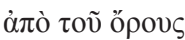

Verse 1 and 2 concern two events derived from Matthew's

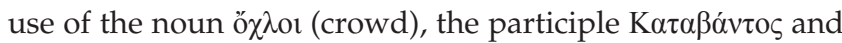
conjunction кai (then) ${ }^{4}$ to reveal the leper's acknowledgment of the divinity of Jesus demonstrated by Jesus' ability to heal and his freedom of choice to do so.

\section{Matthew 8:3: Hand stretching, touching and healing happen simultaneously}

To paint a dramatic picture of the healing of the leper, Matthew categorically introduces the event with his own sentence in 8.3 a before a verbatim recording of the event of the leper's healing by Jesus:

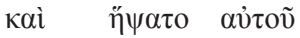

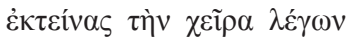

After employing the three verbs describing simultaneous actions of Jesus (stretching, touching and command) to introduce $\theta \dot{\varepsilon} \lambda \omega$ (expressing Jesus' willingness) and $\kappa \alpha \theta \alpha \rho i \sigma \theta \eta \tau ı$

4.First, in verse 1 , ox $x$ ol (crowd), the verb indicative aorist nko koü

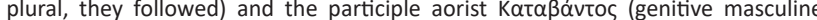
singular, came down) collectively describe Jesus coming down from the mount happening simultaneously with the emergence of a large crowd which paints a narrative picture of a crowd that has either been eagerly searching for Jesus or has earnestly been following Jesus for a period of time. Second, verse 2 is introduced by kai (then), a connective conjunction joining two independent clauses (BDAG kal (then), a connective conjunction joining two independent clauses (BDAG 2000:494) to highlight the emergence of the leprous man in the scene. Because conjunction subordinating $\varepsilon \alpha v$ (if) is uttered by the leper in the context of the verb

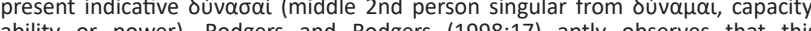
ability or power), Rodgers and Rodgers (1998:17) aptly observes that this conjunction does not indicate the leper's doubt on Jesus "power but rather Jesus' Jesus demonstrated by Jesus' ability to heal, but also his freedom of choice to do so. 
(expressing Jesus' command to heal the leper), ${ }^{5}$ Matthew wraps up the event of healing again with his own words saying: Kaì

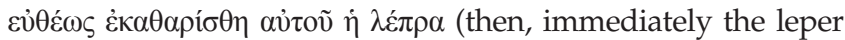
was cleansed/healed). Because in this clause the conjunction Kaì (and so, and then) introduces the result from a preceding clause (BDAG 2000:495) and $\kappa \alpha \theta \alpha \rho i \sigma \theta \eta \tau$ is a passive verb (imperative aorist second person singular, he was healed/ cleansed), this clause unequivocally describes the result of Jesus' commands and action described in the previous clause which in effect espouses the efficacy of the verb $\theta \varepsilon \dot{\lambda} \omega \omega$ (expressing Jesus' willingness) in the narrative.

\section{Matthew 8.4: Priest's testimony and a Mosaic offering confirms the healing}

In verse $4 \kappa \alpha$ (conjunction coordinating that introduces a result from preceding circumstances, and then, and so) signifies that verse 4 , which is characterised by four verbs in the imperative - two in the second person present singular - ö $\rho \alpha$

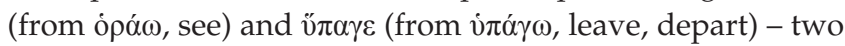
in the aorist singular active $-\delta \varepsilon \tilde{\varepsilon} \xi o v$ (from $\delta \varepsilon i ́ \kappa v v \mu \mathrm{u}$, show) and $\pi \rho \circ \delta \dot{v} \varepsilon \gamma \kappa o v$ (from $\pi \rho о \sigma \varphi \varepsilon ́ \rho \omega$, offer, sacrifice) semantically reveals the superiority of Jesus' words (commands) on the disease described as leprosy and on the leper to anticipate the submission of both leprosy and the leper to Jesus' command of healing. Note that the phrase $\delta \varepsilon i \tilde{\xi}$ ov $\tau \tilde{\omega}$ i $\varepsilon \rho \varepsilon 1$ (show yourself to the priest) is reminiscent of the tradition of the Levitical

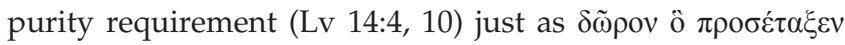

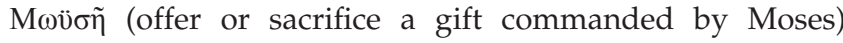
because they both testify to the authenticity of Jesus' healing of the leper.

It is notable from this semantic analysis that the leper's healing (Mt 8:1-4) indicates that Matthew strives to develop a narrative that has the crowd, events of healing, Jesus' commands and Matthew's own words (redaction) collectively contributing to a three-fold progression of the narrative's plot. ${ }^{6}$ If this progression reveals the authors' mindset, the

5.In his own introductory sentence, Matthew sets n̈ $\psi$ ato (a verb indicative constative . In his own introductory sentence, Matthew sets $\eta \psi \alpha$ to (a verb indicative constative aorist-middle $3 r d$ person singular from $\alpha \pi \tau \omega$, touch) that describes the action as
in its entirety, that is, in a summary fashion without taking no interest in the internal workings of the action (Wallace 2000:241) in the literary context of two participles

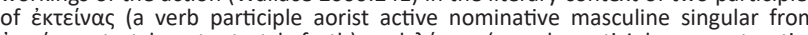
$\dot{\varepsilon} \kappa \tau \varepsilon \dot{v} v \omega$, stretch out, stretch forth) and $\lambda \dot{\varepsilon} \gamma \omega v$ (a verb participle present active nominative masculine singular from $\lambda \dot{\varepsilon} \gamma \omega$, say, speak, tell) to accentuate the occurrence of the leper's healing simultaneously with the stretching out of Jesus' hand and Jesus' touching of the leper. Although this section is translated 'And Jesus put forth his hand, and touched him, saying' (Mt 8:3 KJV) or, 'And Jesus put forth his hand, and touched him, saying' (Mt 8:3 KJV), or, 'And He stretched out His hand and touched him, saying' (Mt 8.3 NAS) these translations tone down the simultaneity of actions in the leper's healing; the stretching of Jesus' hand, touching the leper and actions in the leper's healing; the stretching of Jesus 'hand, touching the leper and the saying (command). This simultaneity of actions associated with the leper's healing is secured by translating the verse to 'And stretching out the hand, he
touched him, saying'.

6.First, Matthew sets his healing narratives (Mt 8-9) in the literary context between the Sermon on the Mount (5.1-7.29) and the commissioning of the disciples (M 10:1-42) who undertake a healing outreach mission. In this literary context, the crowd concludes the Sermon on the Mount (7.28) and opens the next episode on healing narratives (8.1). Carter aptly notes that in Matthew's Gospel narrative the ambivalence presentation of the crowd 'brings awareness of both realities and encourages obedience' to Matthew's community (Carter 1993:67). In this case, we see the crowd witnessing the healing just as they did Jesus' teaching on the Sermon on the Mount. Second, the healing is dramatically presented in the context of actions; the leper prostrates (kneeling to worship Jesus), Jesus stretching out his hand, touching the leper and the leper receives a healing (immediately he is hand, touching the leper and the leper receives a healing (immediately he is heansed) up he also speaks to affect the same. Thirdly, Matthew not only introduces the event with his own words in verse (When Jesus came down from the mount...), but he also concludes the event with his own words saying im from the mount..., but he cleansed" (verse 3). In this narrative we see the progression of the author's thoughts, or mind-set: the event of healing is witnessed by the crowd; it is caused by Jesus actions and commands in response to the leper's request; there is a double climax main question for this article to answer would be: what did Matthew intend to achieve with this narrative of the leper's healing? To answer this question, it is crucial to briefly explore ethnomedical anthropological perspectives to orient ourselves to the interpretive lens, have a look at the healthcare system in the Roman Empire to provide the backdrop for Matthew's narrative of the leper's healing before visiting the community of Matthew in Syrian Antioch.

\section{Ethnomedical anthropological perspective}

This study is guided by Quinlan's definition of ethnomedicine as the 'area of anthropology that studies different society's notions of health and illness, including how people think and how people act about wellbeing and illness' (Quinlan 2011:381). For emphasising the participation of the society rather than professional medical experts only in matters of health, Quinlan's definition present an alternative view to the conventional healthcare derived from Western or conventional conception and practice of medicine.

Consequently, given Quinlan's definition, it implies that medicine can be classified with language, music and politics because it is a subset of culture which is situated locally. In other words, in view of the ethnomedical perspective one's healing is approved not only on account of the patient's acknowledgement, but also such acknowledgment is predicated upon the values and beliefs of the sick person's community. Hence, the aim (or the process of orienting oneself towards their goals or ambitions) of ethnomedical anthropology in research is to unravel the closely intertwined naturalenvironmental, human-biological, and socio-cultural threads that shape the behavioural and conceptual systems of human responses to the experience of illness (Unschuld 1988:179; Wilson 2014:26). Given Quinlan's ethnomedical perspective of medicine, the process of discerning an individual's health status is holistic because it goes beyond western or conventional and industrial expectations to embrace cultural conceptions besides the sick person's conception of the symptoms of illness. How then does ethnomedical anthropology attempt to unravel the biological, social and cultural responses to illness? A twofold conceptual model, namely, explanatory and healthcare system models, has been developed by ethnomedical anthropologist to conduct cross-cultural analysis that explains the dynamics of healing.

\section{Explanatory model}

The 'explanatory model' lends itself to distinguishing between disease and illness. Disease is a biological term that refers to disorders of an organ. Illness refers to culturally recognizable interpretation of diseases within a culture's symbolic world. Explanatory model ascribes etiology of diseases to either the 'natural perspective', that is, explaining diseases based on single causes of symptomology or the 'personalistic perspective, that is, ascribing multivalent effect; Matthew's declaration of the leper's cleansing and the need for the priest to confirm the same (healing/cleansing). 
causes of diseases that are located in the domain of socialcultural relations - with the living persons, ancestors and other supernatural entities (Glessner 2017:21-22; Wilson 2014:27). On the other hand, in ethnomedical anthropology 'healthcare systems' refers to 'the collective view within a given society on matters of illness and health or socially organised responses to disease that constitute a special cultural system' (Kleinman 1980:24; Wilson 2014:27). Derived from Glessner's (2017:18-21) and Wilson's (2014:29-35) classification of the healthcare system, the author prefers a three-fold categorisation of healthcare system: the social, cross-cultural and individual specialist. However, in spite of this three-fold categorisation, these healthcare systems overlap in their functions because it is not only the individual healer but the whole system of healthcare that heals (Glessner 2017:17; Kleinman 1980:415; Wilson 2014:29) as evidenced in the next section concerning the healthcare system in the Roman Empire.

\section{Health care system in the Roman Empire}

\section{Social perspectives}

The social healthcare system is comprised of two sectors namely, cultic and professional.

Cultic Sector: Cultic sector refers to a healthcare system that was spread throughout the Mediterranean region and was formalised in tradition, personnel (priesthoods) and rituals supporting the veneration of healing deities in institutionalised places particularly in the temples (Avalos 1999:49-51; Edelstein \& Edelstein 1945:145-158; Wilson 2014:29-30). For instance, Greek mythology inherited by the Romans, describes Asclepius, a Graeco-Roman god widely associated with healing and medicine, as widely worshipped in the first century CE Roman world for provision of security, health and wealth. Physicians worshipped him as their patron, health people sought blessings from him to sustain their health and cities such as Athens, Syracuse and Pergamum implored his protection against their enemies (Sigerist 1987:63).

Pausanias (circa 110-180 CE), a Greek traveller and geographer in his article Description of Greece (2:27.2) describes the image of Asclepius (shown in Figure 1) as that of ' $[t]$ he god ... sitting on a seat grasping a staff; the other hand he is holding above the head of the serpent' (Crane 2013). This description reveals Asclepius mystical healing powers symbolised and associated with a snake, and a staff. Farnell's observations that earliest tradition of Homer and Hesiod present Asclepius as 'a typical man-god', a real physician of prehistoric era, who was worshipped with historic honours after death and was gradually apotheosized (Farnell 1921:235-238) points to a tradition of healing predicated on mystical power of the divinised Asclepius. This healing power was communicated through a snake as a medium that physically mingled with the sick who would be sleeping in a sanctuary anticipating for Asclepius to appear (to the sick person) in a dream in order for the priest to prescribe the medication to the sick person by interpreting the dream (Farnell 1921:238-242; Pachis 2016:3; Wilson 2014:30).

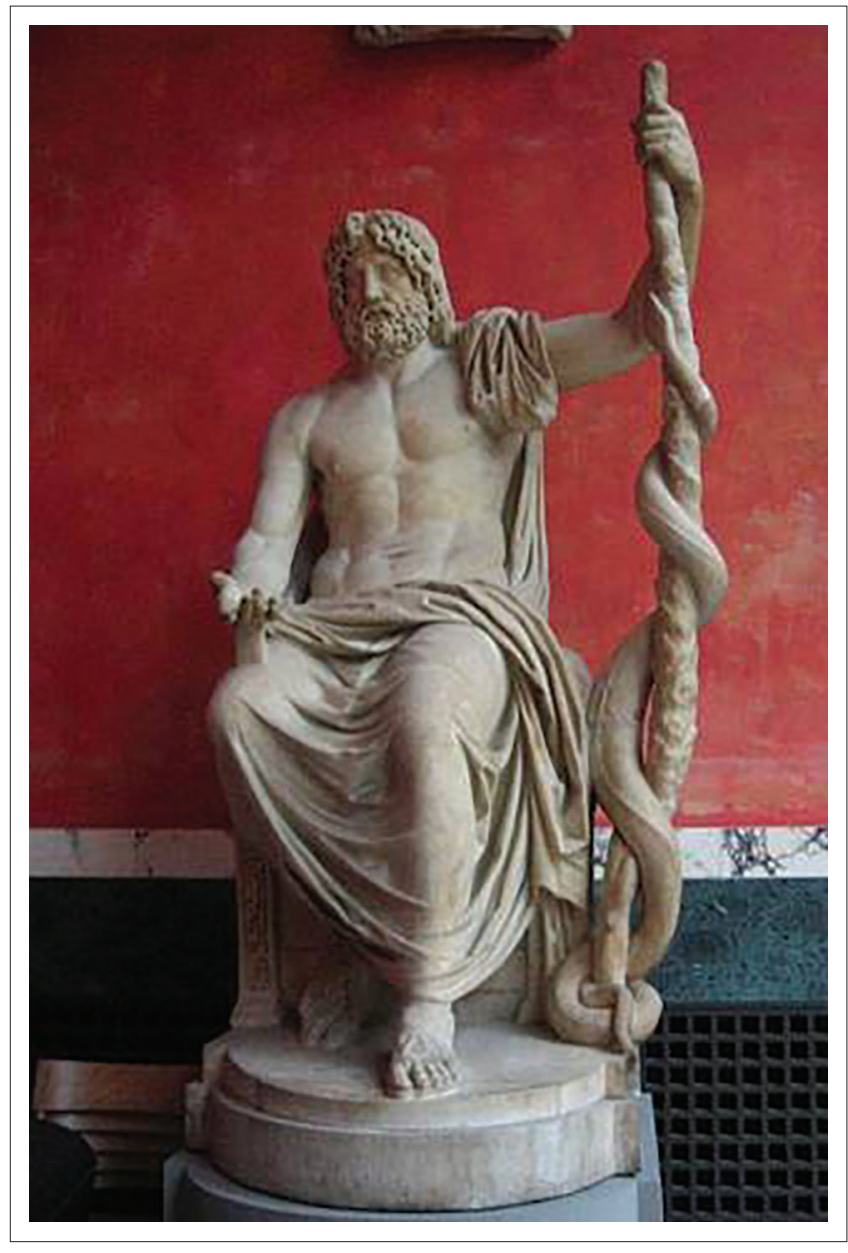

Source: Cartwright, M., 2013, 'Asclepius', in World History Encyclopedia, viewed 10 September 2020, from https://www. worldhistory.org/Asclepius/

FIGURE 1: Asclepius Statue.

Professional Sector: In the ethnomedical perspective, the professional healthcare sector refers to the institutionalised field in medical science comprising credentialized healers who are trained in specialised therapeutic methods according to standards set out by systematised body of therapeutic knowledge (Glessner 2017:19; Pilch 2000:94; Wilson 2014:31). In the Roman Empire, this education-based health sector which was presented as schools of Hippocratic physicians, was credentialized upon the Hippocratic writings (Nutton 1992:15-58, Nutton 2004:53-104; Wilson 2014:31).

On the one hand, Jouanna (1999) noted that in his The Sacred Disease, Hippocrates (shown in Figure 2) disputed divine origin of epilepsy and other diseases to advocate for clinical observations, diagnosis, and prognosis, and argued that specific diseases come from specific causes. On the other hand, in the so called 'Hippocratic Oath', a comparison between the opening statement 'I swear by Apollo the physician, and Asclepius' and the claim that 'I will use those dietary regimens which will benefit my patients according to my...judgments' (Philastratus, Hippocratic Oath. Hp. Jusj.1) collectively portrays an overlap between professional and cultic sector. Glessner correctly notes that although professional medicine was influenced by methods and practices of Hippocrates, most of its activities were carried out in the sanctuaries of Asclepius 


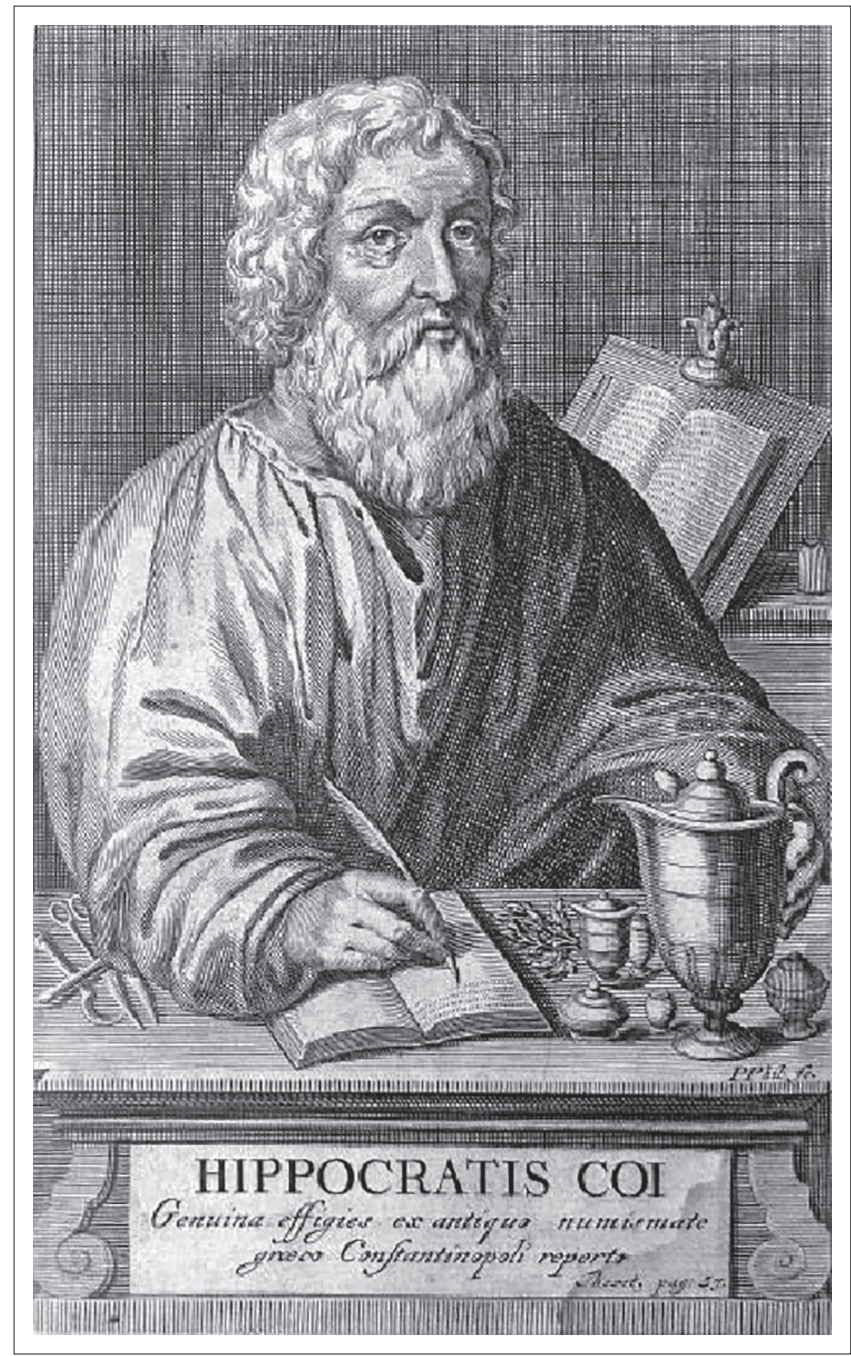

Source: North, M. (ed.), 2002, Hippocratic Oath, viewed 10 September 2020, from http:// www.perseus.tufts.edu/hopper/text?doc=Perseus\%3Atext\%3A1999.01.0252

FIGURE 2: Hippocrates, the physician.

whereby the Asclepius cult blended herbal formulae and medicinal application intrinsically connected with cultic rituals and worship' (Glessner 2017:20). This overlap of the cultic and professional health sector in Hippocrates' practice of medicine not only reveals Hippocrates' allegiance to Asclepius, but also shows his regard for the natural cause of diseases and his use of mediums to effect healing.

\section{Cross-cultural sector}

This cross-cultural healthcare system, which was found across several cultural groups in the Roman Empire, is represented by the folk sector.

Folk Sector: In ethnomedical anthropology, folk sector refers to the non-bureaucratic, non-specialist and popular health sector that was accessible to all classes of people. Although rarely ritual or incantations may accompany the administration of the remedy, there is mostly no religious means of healing associated with the remedy (Glessner 2017:21; Wilson 2014:32). Example of the folk sector is found in 'lyceum', a kind of a flowering plant, whose bitter roots are boiled, mixed with honey and olive oil and according to Pliny this herbal concoction was used for curative purposes of treating various diseases such as '... eyes...cosmetic for the eye...diseases of tonsillary gland...for coughs and discharge of blood from mouth...discharges from wounds...ulcerations of genitals...' (Bostock 1855: Pliny, Nat. Hist. 24:77). Pliny's suggestion shows that folk healers are more easily accessible than either the cultic or professional healers because the cause of the illness is discerned naturally just as the administration of the cure and healing process. Folk sector is a cross-cultural category of healthcare system because it comprises a variety of healers from different cultural groups exhibiting common characteristics such as taking a patient's view of illness at face value. Because in most folk sectors the healers and patients live in close proximity within the social situation of their clients (Glessner 2017:21), it means folk healers share the same cultural group with their patients.

\section{Individual specialist}

Individual specialist healthcare system is represented by charismatic leaders and ascetic sages.

\section{Charismatic}

Charismatic refers to an individual, non-credentialized specialist whose healing authority derives from unusual powers channelled through rituals and various supernatural forces (Theissen 1983:231-246). The charismatic sector depended on the manipulation of supernatural forces or the coercion of a deity to achieve their desired benefit (Meier 1994:549; Wilson 2014:33).

Eleazar, is one such example, whose two methods of healing is noted by Josephus (AJ 8:46-48): one approach is that he could 'put a ring that had a root of one of those sorts mentioned by Solomon to the nostrils of the demoniac, after which he drew out the demon through his nostril'. The second approach is that he could also 'set a little way off a cup or basin full of water and commanded the demon as he went out of the man, to overturn it, and thereby to let the spectators know that he had left the man.' Josephus' suggestion that Eleazar approached his healing in this method in order 'to let the spectators know that he [demon] had left the man; and when the man fell down immediately, he abjured him to return into him no more', suggests the importance of the presence of a crowd to witness the healing. Although Eleazar's therapeutic method overlaps with the professional and cultic sector by manipulating mystical forces as mediums to effect the healing, Josephus' observations that during the healing event Eleazar had to 'still mention of Solomon, and reciting the incantations which he composed' indicates that Eleazar had to confirm to the crowd that his therapeutic approach conformed to Jewish therapeutic tradition.

\section{Ascetic sages}

Ascetic sages' sector refers to itinerary sages who were also seers that embraced various mystical and esoteric GraecoRoman traditions. Like the charismatic sector, the ascetic sector involved exorcism of malevolent spirits that could invade and harm human bodies (Meier 1994:576-578). Apollonius of Tyana, as presented in Figure 3 is one such 


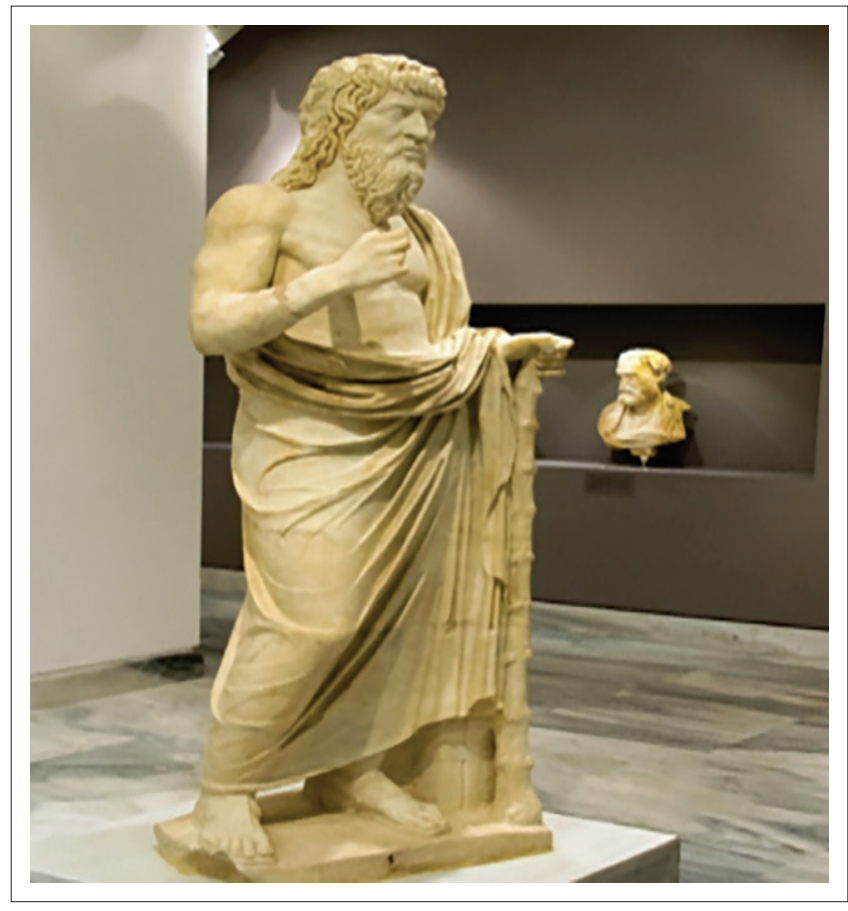

Source: Conybeare, F.C., 2020, Philostratus, Life of Apollonius 3.36-40, viewed 17 August 2021, from https://www.livius.org/sources/content/\%20philostratus-life-of-apollonius/ philostratus-life-of-apollonius-3.36-40/\#3.38

FIGURE 3: Statue of Apollonius of Tyana.

example of the ascetic sector, as noted by Philastratus (circa 170-250 CE) a 2nd century CE biographer.

In the conversation between Apollonius and the mother of a demon possessed boy, Philastratus' (Conybeare 2020, Life of Apollonius 3:38-39) observation that the demon had threatened her with steep places and precipices and declared that he would kill her son' locates the cause of illness in a malevolent spirit. According to Philastratus, Apollonius exorcised the demon through the medium of a letter that 'he drew... out of his bosom and gave it to the woman' and it 'was addressed to the ghost'. Philastratus was convinced that Apollonius' letter could exorcise the boy from evil spirit because he believed the letter 'contained threats of an alarming kind' which could scare away the demon.

Given this social and cross-cultural healthcare system that was spread all over the Roman Empire which in effect marked the backdrop of the emergence of the community of Matthew in Antioch, one would want to know: how would Matthew have intended to use the leper's healing narrative in his community?

\section{Matthew's community in Syrian Antioch \\ Syrian Antioch}

Given the internal evidence which indicates that in his narrative, Matthew was greatly concerned with Syria (4.24), and supporting external evidence from writers such as that of Ignatius in 'New Advent: Church Fathers' (Smyr 1:1-2) (Knight 2020), the provenance of Matthew's Gospel can be identified as Antioch (Slee 2003:122-125). In the first-century
Roman Empire, Antioch had become the capital city of the Near East because it was strategically used by Rome for military campaigns, and Emperor Domitian contributed baths and a temple for Asclepius (Morey 1936:643-644). Archaeological excavations indicate that temples of Isis, Serapis and Demeter were also found in Antioch (Norris 1982:193-194). Figure 4 presents the remains of the image of an Asclepius temple at Epidaurus, native home to Asclepius.

To describe how this multicultural complexity of the Syrian Antioch city could have occasioned Matthew's use of the narrative of the leper's healing as a response to the multicultural health system available in the Syrian Antioch city, it is important to investigate how the leper's healing shaped Matthew's conception of etiologies of sickness, his therapeutic strategies and the significance of these strategies for him and his community.

\section{Matthew's perspectives of etiologies of illness}

In Hebrew צָר (tsara'at) refers to suffering from skin eruption or struck with a skin disease, though translated 'leprous' which for today's context may not be accurate, entails a spectrum of skin disease such as psoriasis and vitiligo (Carter 2000:199; Viljoen 2014:2; Wilson 2014:39). From the ethnomedical anthropological perspective, two causes could be attributed to the genesis of leprosy. The text locates the causation of the leper's diseases on natural causation on account of the leper's plea for healing (Mt 8:2c) and confession of the illness ( $\mathrm{Lv}$ 13:44) on the one hand. On the other, a personalistic causation is discernible on account of the Levitical code of purity demand for the isolation of a leper and only to be accepted back to interact with the society on account of the Priest's confirmation (Mt 8:4b; Lv 13:50-59) because the cause of leprosy resulted from a breach of a longstanding taboo among the Jews (Glessner 2017:22). Although Josephus (AJ 3:261, 264) suggests that healing of leprosy happened through prayers to God, inevitably, the cause of the illness as a result of leprous was largely culturally conceived by the society, though the bearer of the sickness could confirm its presence by confessing the symptoms of the diseases or by seeking for healing.

\section{Matthew's therapeutic strategies}

Matthew's (8.3b) observation of Jesus's commanding the

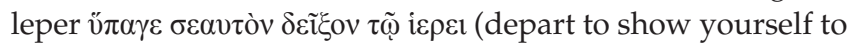

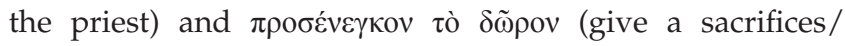
offering) locates the healing narrative within the cultic healthcare system because of the reference to the priest and act of offering which normally happened in the temple. The importance of this cultic perspective of healing, as noted by Viljoen, is that it 'restored the leper's social stance and gave him new meaning' (Viljoen 2014:5) that granted the leper some honour and freedom to interact with the society. Besides this social function of healing, there is also a cultural perspective to it that can be inferred from the healing of a leper emphasised by Jesus' instructions that the offering/ sacrifice to the priest (8.4b) must be done according to 


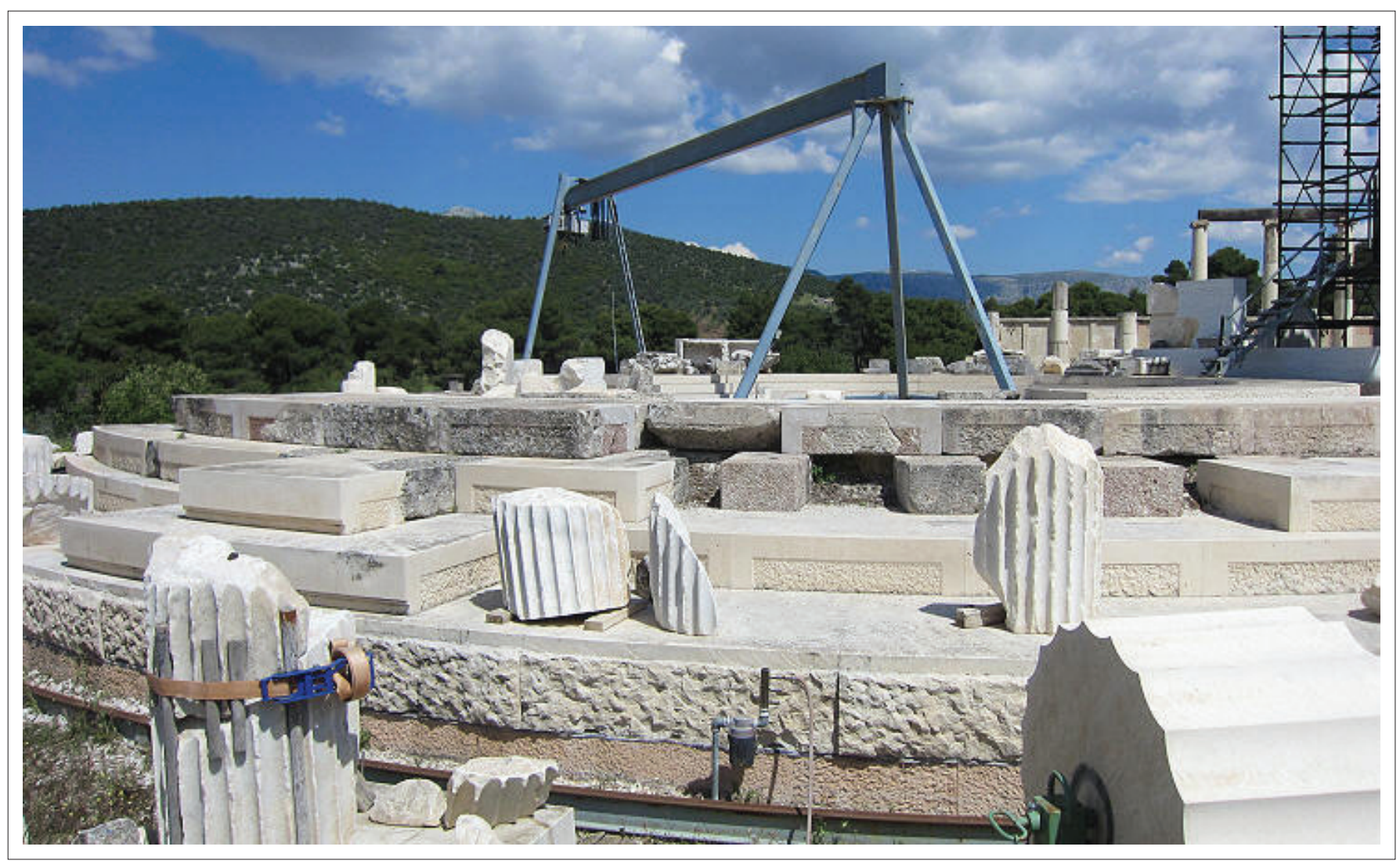

Source: Piperno, R., n.d., 'Temple of Asclepius at Epidaurus', Rome in the footsteps of an XVIIIth century traveler, viewed 25 April 2021, from https://www.romeartlover.it/Epidauro.html FIGURE 4: Temple of Asclepius at Epidaurus.

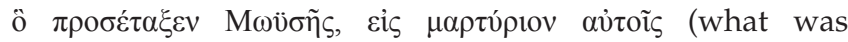
commanded/ordered by Moses as a witness to them) points to the status of Jesus as a professional healer. Mary Douglas' view that according to the Levitical code the human body functions as a model of Israel's society particularly as a model for the temple (Douglass 2000:66-86), from an ethnomedical anthropological heightens the characteristics of the professional healthcare system envisioned by Matthew in the healing of the leper in reference to Jesus' meeting all the expectations of healing in Israel's temple particularly as instructed in the Levitical code of purity (Lev 13.34-59). On account of this, we can postulate that just as in the Roman Empire the authenticity of the professional medical health sector was qualified on account of meeting the standards of the Hippocratic tradition, so is the authenticity of Jesus' role as a physician was qualified on account of the leper's healing conforming to standards set out in Levitical code of purity.

In addition to the professional and folk sector, Matthew's healing of a leper portrays characteristic of a first century CE individual specialist healthcare sector in two fronts. On the

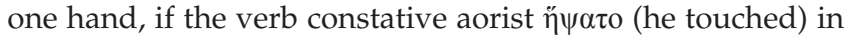
8.3a (Wallace 2000:240) is viewed in the context of Jesus' declaration of $\theta \dot{\varepsilon} \lambda \omega$ (I will), the narrative emphasises a charismatic sector character of the healing by pointing out that the healing power voluntarily originates from Jesus. On the other hand, Jesus' wandering from one place to another, for instance, Capernaum (8:5), Gadaranes (8:28), Nazareth (9:1) and several cities and villages (9:35) healing people who suffered from a myriad of diseases including but not limited to exorcising malevolent spirits that could harm human bodies (Wilson 2014:33), portrays characteristics of an ascetic sage.

Given that the healing of the leper portrays Jesus as a holistic healer who embodied the characteristics of most of the healthcare system of the first century $\mathrm{CE}$, there is no doubt that the healing of a leper reveals a mindset (ideology) of Matthew regarding the event of Jesus healing a leper. This mindset is further revealed by Matthew's redaction of other sources to create his narrative. Adapting to the view that Matthew relied on two sources - Mark and Q (Germany Quelle: Source) - to build his Gospel narrative (Davies \& Allison 1988:97-127; Wilson 2014:8), it seems Matthew derived his narrative of the leper's healing from a longer narrative found in Mark 1:40-45. In redacting the Markan source, Matthew adds his own words 'As he was coming down from the mountain, great a crowd followed him' (Mt 8:1a) to introduce the leper. Matthew also avoids Mark 1.45 to join the leper's healing with Jesus' movement to Capernaum. With this kind of redaction and many more in the narrative, Matthew strives to use the narrative of the healing of the leper to achieve particular ideological significance which can only be clearly envisioned by reviewing the narrative in its social setting in the Roman Empire.

\section{Significance of Matthew's therapeutic strategies}

In this section, Vernon Robbins' (1996:193) perspective of ideology which he defines as '....an integrated system of beliefs, assumptions and values...which reflect the needs and interests of a group or class at a particular time' is 
instructive. In effect, Robbins suggests that ideology refers to a communication of a power predicated on a mind-set signified by a text whose interest is to promote the beliefs, values and assumptions either of the text, audience or the author (M'bwangi 2020:5). Since the article attempts to advance Wilson's position that the connection of the narrative of the leper's healing (Mt 8.1-4) with Matthew chapter 11 contributes to the theme of Christology (Wilson 2014:16), to accomplish this task from an ideological perspective, it is crucial to answer this question: how does the leper's healing (8.1-4) portray a perspective of a Christology that signifies the power of either the text, author or audience which is based on a system of beliefs or values?

Matthew's reduction of earlier sources to compose the narrative of the leper's healing $(8: 1-4)$ in the literary context of 8:5-11:28 has resulted in the creation of a text embedded with power to communicate the superiority of the person and ministry of Jesus. The ideological perspective of power is not only portrayed by the holistic healthcare system derived from Jesus as opposed to the rest of the health care systems of the time, but also the attraction of the crowd $(4: 25 ; 5: 1 ; 7: 28-29 ; 8: 1)$ to Jesus' ministry which denotes a physical movement of people (not of disciples) in response to Jesus. Carter (2000:198) places the popularity of Jesus' healing above all the healing available either in cultic, professional, folk or individual specialist sectors because it attracted a multicultural crowd. This superiority of Jesus communicated here presents Matthew's contribution to the early church regarding the significance of the transcendent Christological title of 'I 'Inбoṽ was not only valuable to the members of the Jesus Movement in first century CE because it provided a belief system that worshipped Jesus as Lord and Savior of humankind (Phlp 2:6, 9-11; Ac 16:31), but it also provided a value system for guiding members of the Jesus Movement to make a decision, for instance, to accord more allegiance to Jesus than to the emperor (Ac 4:1-23; 5:29).

Besides espousing the transcendent perspective of Christology, Jesus' touch and command that simultaneously caused the healing (Mt 8:3), ideologically subordinates all the other methods of healing of healthcare systems in the Roman Empire to that of Jesus which in effect accentuates the immanent perspective of Matthew's Christology. While these other healers required the aid of a medium/agent to effect the healing, the healing power of Matthew's Jesus emanated from himself voluntarily and directly. Consequently, the subordination of these other healers to Jesus' self-charged healing power inevitably espouses Matthew's immanent Christology grounded in the concept of Emmanuel (1:23), 'God with us'.

The superiority of Jesus to ground transcendent Christology and subordinate healing methods available in the Roman Empire to procure immanent and transcendent perspectives of Christology are crucial in the identity reconstruction and sustenance of Matthew's community. Prof. Wanamaker's (2002:133) argument that the reconstruction of identity involves a resocialisation process, in which 'one universe of discourse or set of shared or common social meanings is replaced by another', is instructive. By reciting the belief systems that portray Jesus' transcendence and immanence on account of his healing ministry in the context of other healers in the Roman Empire, the community of Matthew will not only be reconstructing their identity by making these beliefs and value systems normative to them, but they will also be sustaining self-knowledge of who they are in the society.

\section{Conclusion}

The article has attempted to answer the question of what Matthew may have intended to achieve with his narrative of the leper's healing in 8:1-4. The pathway to answering this question has made it necessary to briefly explore other scholars' suggestions on the leper's narrative to provide a basis for deriving the question before a semantic analysis of Matthew 8:1-4 to explore Matthew's narrative in the text. A brief survey of the health sectors in the Roman Empire, namely, cultic, professional, folk and individual specialist was crucial not only in providing the social setting of the leper's healing narrative, but also in providing the backdrop for supporting the argument that employing ethnomedical anthropology as a lens to read the leper's healing narrative in Matthew 8:1-4 in the context of Matthew's social setting reveals Matthew's ideology for a transcendent and immanent Christology. To this end, archaeological artefacts and the writings of Pausanias, Hippocrates, Pliny, Josephus and Philastratus primarily provide the sources for the social setting of the narrative. The finding derived from this research establish that although Jesus embraces a holistic healing ministry suitable for establishing a holistic healthcare system, to effectively embrace a holistic healthcare system for a given society, it is crucial to consider the social and cultural healthcare systems available in that society. This is not only important in determining the relevance of Jesus' holistic ministry in the society, but it also has the capacity to reveal indigenous knowledge regarding the social and cultural conception and practices of healthcare in the society. Thus, the study tentatively demonstrates the importance of using ethnomedical anthropology as a lens for future research interested in finding out how biblical healing narratives could be used to address social and cultural perspectives of health issues in the society, particularly in Africa. To this end, this article provides the platform for a project which the author intends to undertake in the near future whereby the plan is to use a theory that blends ethnomedical anthropology with an African lens derived from concepts of Ubuntu, African Community and Ujamaa (Baert et al. 2012:663-681; Abrahams 2016:304-334; Modise 2020:1-16) to investigate the healing of the woman with Haemorrhage in Matthew 9:20-22 in light of medieval culture to debunk myths on universal masculinity in the Anglican Church leadership in Africa.

\section{Acknowledgements}

I would like to register my heartfelt gratitude to the following people; first and foremost to Prof Dr Ernest van Eck for 
allowing me to participate in the 'African Platform for NT Scholars' project; Dr Zorodzai Dube (Snr Lecturer, Department of New Testament and Related Literatures, University of Pretoria, South Africa) for his mentorship role in my postdoctoral research at the University of Pretoria; Dr Ali Awadh Hemed (HoD Philosophy \& Religious Studies, Pwani University, Kenya) and Associate Prof Dr. Steven Muoki Joshua (Director of the Board of Undergraduate Studies, Pwani University) for respectively endorsing my post-doctoral research fellowship at the University of Pretoria, and frequently checking on me while pursuing the postdoctoral research at a time when the Coronavirus is reigning havoc on all aspects of human life.

\section{Competing interests}

The author declares that he has no financial or personal relationships that may have inappropriately influenced him in writing this article.

\section{Author's contributions}

F.M.M. is the sole author of this article.

\section{Ethical considerations}

This article followed all ethical standards for research without direct contact with human or animal subjects.

\section{Funding information}

This research received no specific grant from any funding agency in the public, commercial or not-for-profit sectors.

\section{Data availability}

Data sharing is not applicable to this article as no new data were created or analysed in this study.

\section{Disclaimer}

The views and opinions expressed in this article are those of the author and do not necessarily reflect the official policy or position of any affiliated agency of the author and the publisher.

\section{References}

Abrams, J.R., 2016, 'Debunking the myth of universal male privilege', University of Michigan Journal of Law Reforms 49, 304-334.

Avalos, H., 1999, Health care and the rise of the Christianity, Hendrickson, Peabody, MA.

Baert, B., Kusters, L. \& Sidgwick, E., 2012, 'An issue of blood: The healing of the woman with the hemorrhage (Mark 5.24B-34; Luke 8.42B-48; Matthew 9.19-22) in early medieval visual culture', Journal of Religion and Health 51(3), 663-681. https:// doi.org/10.1007/s10943-012-9618-5

BDAG, 2000, Greek-English Lexicon of the New Testament and other early Christian literatures, 3rd edn., University of Chicago Press, Chicago, IL.

Bostock, J., 1855, 'Pliny the Elder: The Natural History' Perseus Digital Library, viewed 02 April 2021, from http://www.perseus.tufts.edu/hopper/?doc=Perseus:text

Carruthers, J. (ed.), 2020, 'Public statement on Covid-19', South Africa Journal of Science 116 (7/8), 32-33.

Carter, W., 1993, 'The crowds in Matthew's Gospel', Catholic Biblical Quarterly 55, 54-67.

Carter, W., 2000, Matthew and the margins, Orbis Books, Mary Knoll.
Cartwright, M., 2013, 'Asclepius', in World History Encyclopedia, viewed 10 September 2020, from https://www. worldhistory.org/Asclepius/.

Conybeare, F.C., 2020, Philostratus, Life of Apollonius 3.36-40, viewed 17 August 2021, from https://www.livius.org/sources/content/\%20philostratus-life-of-apollonius/ philostratus-life-of-apollonius-3.36-40/\#3.38.

Crane, G.R., 2013, 'Pausanias: Description of Greece' Perseus Digital Library, viewed 10 April 2020, from http://www.perseus.tufts.edu/hopper/text?doc=Perseus\%3A text\%3A1999.01.0160.

Davies, W.D. \& Allison, D.A., 1988, The Gospel according to Saint Matthew, International Critical Commentary, vol. 1, T \& T Clark, London.

Douglass, M., 2000, Leviticus as literature, Oxford Press, Oxford.

Dube, Z., 2018, 'Models and perspectives concerning the identity of Jesus as healer', HTS Teologiese Studies/Theological Studies 74(1), 1-6. https://doi.org/10.4102/ hts.v74i1.4925

Edelstein, E.J. \& Edelstein, L., 1945, Asclepius, collections and interpretations of the testimonies, vol. 2, John Hopkins University Press, Baltimore, MD.

Farnell, L.R., 1921, Greek heroes, cults and ideas of immortality, Clarendon Press, Oxford.

Glessner, J.M., 2017, 'Ethnomedical anthropology and Paul's "Thorne" (2 Corinthians 12:7)', Biblical Theology Bulletin 47(1st November), 15-46. https://doi. org/10.1177/0146107916682197

Jouanna, J., 1999, Hippocrates, Johns Hopkins University Press, Baltimore, MD.

Kleinman, A., 1980, Patients and healers in the context of culture, University of California Press, Berkeley, CA.

Knight, K., 2020, 'Ignatius of Antioch', Fathers of the Church, viewed 10 April 2020, from the https://www.newadvent.org/>fathers/.

M'bwangi, F.M., 2020, 'Righteousness, ideology and the kingdom of god in Matthew 6:10 - A reading of identity politics from Matthew's lord's prayer', Pharos Journal of Theology 101, 1-12.

Meier, J.P., 1994, A marginal Jew: Mentor, message and miracles, vol. 2, Rethinking the Historical Jesus, Doubleday, New York, NY.

Modise, L., 2020, 'Reading the UCSA church order with African lenses: A Belhar confession. Perspective', Studia Historiae Ecclesiastecae 46(3), 1-16. https://doi. org/10.25159/2412-4265/7014

Morey, C.R., 1936, 'The excavation of Antioch-on-the-Orontes', Proceedings of the American Philosophical Society 76(5), 637-651.

Morris, L., 1992, The Gospel according to Matthew, Wm. B. Eerdmans Publishing, Cambridge.

Naicker, I., 2020, Voices missing from South African response to COVID-19, viewed 10 September 2020, from https://bloomgist.wordpress.com /tag/south-africa/.

North, M., 2002, 'Hippocrates, Hippocratic Oath', National Library of Medicine, viewed 10 April 2020 from, http://www.perseus.tufts.edu/hopper/text?doc=Perseus\%3 Atext\%3A1999.01.0252.

Norris, F.W., 1982, 'Isis, Serapis and Demeter in Antioch of Syria', Harvard Theological Review 75(2), 189-207. https://doi.org/10.1017/S0017816000018307

Nutton, V., 1992, 'Healers in the medical market place: Towards a social history of Graeco-Roman medicine', in A. Wear (ed.), Medicine in society. Historical essays, pp. 15-58, Cambridge University Press, Cambridge.

Nutton, V., 2004, Ancient medicine, Routledge, London.

Pachis, P., 2016, 'Healing gods, heroes and rituals in the Greco-Roman world', Open Library Humanities 2(1:e14), 1-10. https://doi.org/10.16995/olh.105

Pilch, J.J., 2000, Healing in the New Testament: Insights from medical and Mediterranean anthropology, Fortress Press, Minneapolis, MN.

Piperno, R., n.d., 'Temple of Asclepius at Epidaurus', in Rome in the footsteps of an XVIIIth century traveler, viewed 25 April 2021, from https://www.romeartlover.it/ Epidauro.html.

Quinlan, M.B., 2011, 'Ethnomedicine', in M. Singer \& P.I. Erickson (ed.), A companion to medical anthropology, pp. 381-403, Wiley-Blackwell Publications, Malden, MA.

Robbins, V.K., 1996, Exploring the texture of texts, Trinity Press International, Harrisburg.

Rodgers III, C.L., 1998, The new linguistic and exegetical key to the Greek New Testament, Zondervan Academic, Grand Rapids, MI

Sigerist, H.E., 1987, A history of medicine: Volume 2: Primitive and archaic medicine, Oxford University Press, Oxford.

Slee, M., 2003, The church in Antioch in the first century: Communion and conflict, Sheffield, London.

Theissen, G., 1983, The miracle stories of the early Christian tradition, Fortess Press, Philadelphia, PA.

Unschuld, P.U., 1988, 'Culture and pharmaceutics', in S. Van der Geest \& S.R. Whyte (eds.), The context of medicines in developing countries: Studies in pharmaceutical anthropology, pp. 179-197, Kluwer Academy, Dordrecht.

Viljoen, F.P., 2014, 'Jesus healing the leper and the purity law in the Gospel of Matthew', Die Skriflig 48(2), 1-7. https://doi.org/10.4102/ids.v48i2.1751

Wallace, D.B., 2000, The basics of New Testament syntax: An intermediate Greek grammar, Zondervan, Grand Rapids, MI.

Wanamaker, C.A., 2002, 'Apocalyptic discourse, paraenesis and identity maintenance', Neotestamentica 36(1/2), 131-145.

Wilson, W.T., 2014, Healing in the Gospel of Matthew, Fortress Press, Minneapolis, MN. 